\title{
Analisis Banjir Subdas Cimanuk Untuk Menentukan Status Peringatan Dini Banjir Kota Garut
}

\author{
Jennifer Gerina Putri ${ }^{1}$, Suharyanto ${ }^{2}$, Pranoto Samto Atmojo ${ }^{3}$ \\ Mahasiswa Magister Teknik Sipil, Universitas Diponegoro Semarang ${ }^{1}$, Dosen Magister Teknik Sipil, \\ Universitas Diponegoro Semarang ${ }^{2,3}$ \\ Email: jennifergerinaputri@ gmail.com ${ }^{1}$ \\ DOI: http://dx.doi.org/10.31869/rtj.v4i2.2369
}

\begin{abstract}
Abstrak: Kabupaten Garut khususnya Kawasan Kota Garut merupakan daerah dengan potensi bencana banjir yang tinggi. Kawasan Garut masih dinyatakan sebagai daerah rawan bencana. Hal tersebut berdasarkan hasil laporan dari Badan Penanggulangan Bencana Daerah (BPBD) Kabupaten Garut. Kawasan Kota Garut dilalui oleh Sungai Cimanuk yang berhulu di Pegunungan Mandalagiri di Kabupaten Garut mengalir ke dan bermuara di Laut Jawa di Kabupaten Indramayu.

Pada tanggal 21 September 2016, Garut mengalami banjir bandang yang banyak menyebabkan

korban jiwa. Banjir yang menimpa Kota Garut disebabkan oleh buruknya kondisi DAS Cimanuk, dikarenakan alih fungsi tata guna lahan. Selain upaya struktural, kerusakan dan kerugian dapat diminimalisir dengan upaya nonstruktural yaitu peringatan dini banjir.

Peringatan dini banjir pada penelitian ini melakukan analisis banjir menggunakan pemodelan

hidrologi dan hidrolika, dimana analisis hidrologi dilakukan di DAS Cimanuk Hulu mulai dari Kecamatan Cikajang Kabupaten Garut, hingga batas daerah genangan Waduk Jatigede di Kecamatan Wado Kabupaten Sumedang. Analisis hidrolika dilakukan mulai Bendung Cimanuk di Kecamatan Bayongbong hingga Bendung Copong di Kecamatan Garut Kota.

Hasil analisis berdasarkan kala ulang 2, 5, 10, 25, 50 dan 100 tahun menunjukan bahwa debit banjir Q5, Q10, Q25, Q50 dan Q100 berpotensi menimbulkan bencana banjir di 9 desa atau 6 kecamatan yaitu Kecamatan Bayongbong, Cisurupan, Cilawu, Garut Kota, Tarogong dan Banyuresmi. Waktu tempuh desa yang berada di luar Kawasan Kota Garut adalah Desa Bayongbong dan Desa Cilea di Kecamatan Bayongbong yaitu 0.1 jam (6 menit) jika banjir terjadi dengan $Q \geq Q 50$ tahun. Untuk desa yang berada di dalam Kawasan Kota Garut adalah Desa Sukakarya dan Desa Cisurupan di Kecamatan Bayongbong, yaitu 1.5 jam (90 menit) jika banjir terjadi dengan Q $\geq$ Q50 dan Q100 tahun. Warga mulai evakuasi saat status level peringatan dini menunjukkan peralihan dari level Siaga ke level Awas.
\end{abstract}

Kata kunci: banjir, peringatan dini banjir, waktu tempuh, Kota Garut, DAS Cimanuk Hulu

\section{PENDAHULUAN}

Sistem peringatan dini dan evakuasi merupakan salah satu bentuk manajemen penanganan bencana. Sistem peringatan dini dilakukan untuk pengambilan tindakan cepat dan tepat dalam rangka mengurangi resiko terkena bencana, serta mempersiapkan tindakan tanggap darurat. Sedangkan tindakan evakuasi merupakan suatu bentuk perlindungan terhadap kelompok yang rentan terhadap bencana, yang secara efektif dan efisien memerlukan kerjasama lintas sektoral dan diterapkan sesuai peraturan pemerintah Republik Indonesia yang berlaku, yaitu Undang-Undang Republik Indonesia Nomor 24 Tahun 2007 (PSN Kementerian PU, 2012).

Kabupaten Garut merupakan daerah dengan potensi bencana banjir yang tinggi. Kawasan Kabupaten Garut masih dinyatakan sebagai daerah rawan bencana. Hal tersebut berdasarkan hasil laporan dari Badan
Penanggulangan Bencana Daerah (BPBD) Kabupaten Garut. Rekap laporan yang dilakukan BPBD Kabupaten Garut hingga semester pertama 2014 (Bencanakesehatan.net).

Penelitian ini mengambil pembahasan dari kejadian bencana banjir yang terjadi di Kabupaten Garut, khususnya di Kawasan Kota Garut, yang banyak menyebabkan korban jiwa yaitu kejadian banjir pada tanggal 21 September 2016. Volume air yang begitu banyak masuk ke badan sungai, menyebabkan longsoran di dinding sungai yang kemudian membendung dan menahan air, hingga akhirnya jebol dan menyebabkan banjir bandang di Sungai Cimanuk. Banjir yang meluap terutama di Kecamatan Tarogong Kidul di DAS Cimanuk dengan ketinggian mencapai 1,5 - 2 meter dan banyak yang sampai melewati atap rumah penduduk (BBC News, 2016). Pada sepanjang Sungai Cimanuk belum ada

\begin{tabular}{lll}
\hline ISSN 2599-2081 & Fakultas Teknik UMSB & 229
\end{tabular}

EISSN 2599-2090 
peringatan dini yang terintegrasi dengan baik. Maka dari itu perlu dan sangat dibutuhkan analisis banjir dimana adalah maksud dari penelitian ini yaitu untuk menentukan status level peringatan dini banjir di Kota Garut, untuk memberikan informasi dan peramalan kejadian banjir kepada masyarakat.

Ruang lingkup lokasi penelitian yaitu di Kawasan Kota Garut yang rawan banjir untuk rencana peringatan dini, yang dilalui oleh Sungai Cimanuk Hulu sepanjang $70 \mathrm{~km}$.

Analisis pemodelan hidrologi dengan menggunakan program HEC-HMS v.4.2.1 dimodelkan pada DAS Cimanuk Hulu, yaitu dari Sungai Cimanuk di Kecamatan Cikajang, Kabupaten Garut sampai dengan Desa Cikarao, Kecamatan Wado, yang terletak di batas daerah genangan Waduk Jatigede Kabupaten Sumedang. Analisis pemodelan hidrolika dengan menggunakan program HEC-RAS v.5.0.3 dimodelkan mulai dari Bendung Cimanuk di Desa Mulyasari Kecamatan Bayongbong, hingga Bendung Copong di Desa Mekarsari Kecamatan Banyuresmi.

Analisis peringatan dini banjir di Sungai Cimanuk merupakan peringatan dini dengan indikator tinggi muka air berdasarkan kala ulang 2, 5, 10, 25, 50 dan 100 tahun.

\section{METODOLOGI PENELITIAN}

Pemahaman terhadap wilayah studi merupakan salah satu tahap penting dalam penelitian. Penelitian dimulai dari pengumpulan data berupa data sekunder dan data pendukung. Secara umum, prosedur penelitian ini dilakukan secara bertahap yaitu pengumpulan data, analisis hidrologi menggunakan program HEC-HMS v.4.2.1, analisis hidrolika menggunakan program HECRAS v.5.0.7 dan analisis peringatan dini banjir Kota Garut yang dilalui Sungai Cimanuk. Tahapan penelitian untuk selengkapnya pada Gambar 1 berikut.

Jenis data yang digunakan untuk penelitian ini adalah data sekunder dan data pendukung lainnya. Data sekunder adalah data yang didapatkan dengan mencari informasi secara ilmiah pada instansi ataupun lembaga-lembaga yang terkait dalam perencanaan normalisasi sungai ini. Data sekunder biasanya merupakan arsip lama maupun data kondisi terbaru. Data sekunder pada penelitian ini yaitu:

1. Data Hidrologi

Stasiun yang digunakan adalah sebanyak

11 stasiun hujan yang terletak di DAS

Cimanuk Hulu, ditampilkan pada Tabel 1 berikut.

2. Data Hasil Foto Udara UAV (Unmanned Aerial Vehicle)

Data hasil foto udara menggunakan pesawat tanpa awak (Unmanned Aerial Vehicle) mencakup data orthophoto dan DSM (Digital Surface Model) atau DTM (Digital Terrain Model). DSM merupakan model elevasi yang menampilkan ketinggian permukaan. 


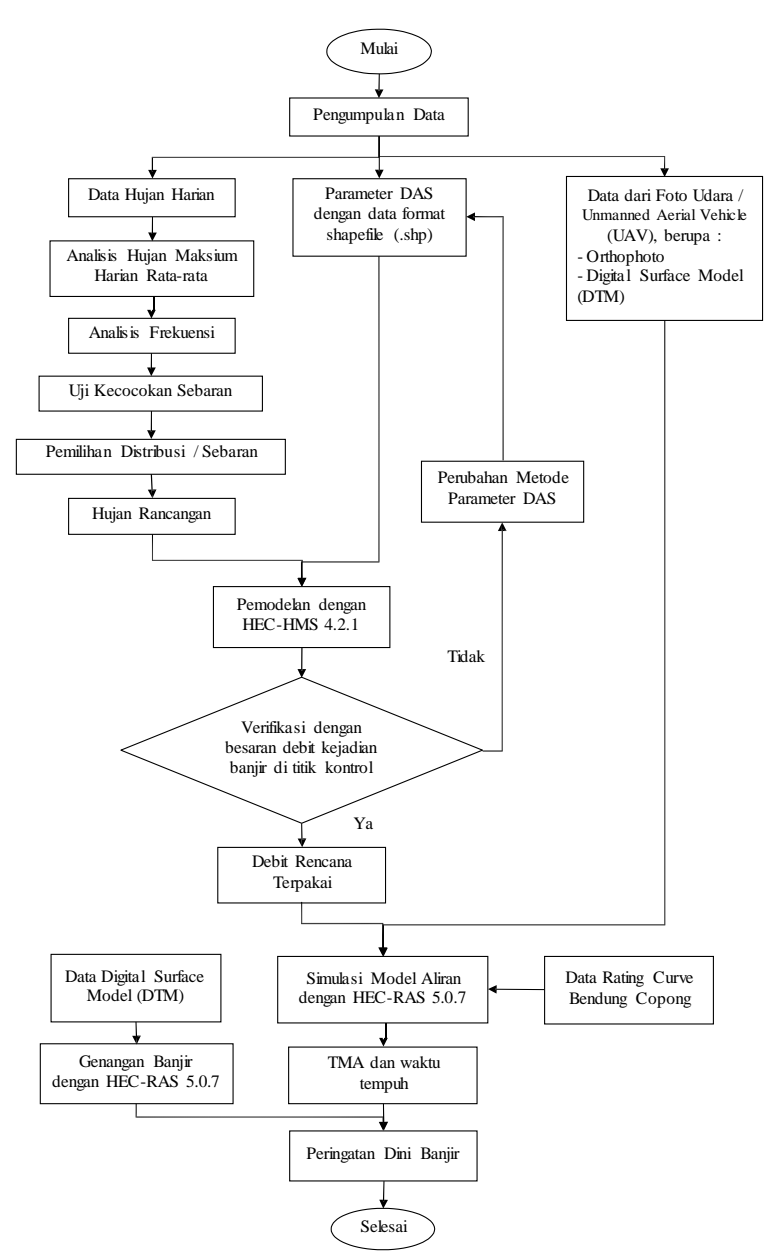

Gambar 1. Bagan Alir Tahapan Penelitian

Jika DTM hanya menampilkan ground (permukaan tanah tanpa apapun yang diatasnya) maka DSM menampilkan bentuk permukaan apapun yang ada seperti ketinggian pohon, bangunan dan objek apapun yang ada diatas tanah. Data hasil foto udara mencakup geometri sungai sepanjang $70 \mathrm{~km}$ dengan skala $1: 5000$.

Tabel 1. Stasiun Hujan yang Dipakai

\begin{tabular}{|l|l|l|}
\hline Nama Sta. & $\begin{array}{l}\text { Lokasi (Desa / } \\
\text { Kelurahan, }\end{array}$ & \multicolumn{1}{|c|}{ DAS } \\
\hline Papandayan & $\begin{array}{l}\text { Pakenjeng, } \\
\text { Pamulihan }\end{array}$ & $\begin{array}{l}\text { Luar DAS } \\
\text { Cimanuk }\end{array}$ \\
\hline Cikajang & $\begin{array}{l}\text { Cikajang, } \\
\text { Cikajang }\end{array}$ & $\begin{array}{l}\text { Cimanuk } \\
\text { Hulu }\end{array}$ \\
\hline Bayongbong & $\begin{array}{l}\text { Ciburuy, } \\
\text { Bayongbong }\end{array}$ & $\begin{array}{l}\text { Cimanuk } \\
\text { Hulu }\end{array}$ \\
\hline Samarang & $\begin{array}{l}\text { Padasuka, } \\
\text { Samarang }\end{array}$ & $\begin{array}{l}\text { Cimanuk } \\
\text { Hulu }\end{array}$ \\
\hline Garut Kota & $\begin{array}{l}\text { Ngamplangsari, } \\
\text { Cilawu }\end{array}$ & $\begin{array}{l}\text { Cimanuk } \\
\text { Hulu }\end{array}$ \\
\hline Limbangan & $\begin{array}{l}\text { Majasari, } \\
\text { Limbangan }\end{array}$ & $\begin{array}{l}\text { Cimanuk } \\
\text { Hulu }\end{array}$ \\
\hline wWanaraja & $\begin{array}{l}\text { Sadang, } \\
\text { Wanaraja }\end{array}$ & $\begin{array}{l}\text { Cimanuk } \\
\text { Hulu }\end{array}$ \\
\hline
\end{tabular}

\begin{tabular}{|l|l|l|} 
Nama Sta. & $\begin{array}{l}\text { Lokasi (Desa / } \\
\text { Kelurahan, }\end{array}$ & \multicolumn{1}{c|}{ DAS } \\
\hline Sukawening & $\begin{array}{l}\text { Caringin, } \\
\text { Sukawening }\end{array}$ & $\begin{array}{l}\text { Cimanuk } \\
\text { Hulu }\end{array}$ \\
\hline Leuweungtiis & $\begin{array}{l}\text { Haruman, } \\
\text { Leles }\end{array}$ & $\begin{array}{l}\text { Cimanuk } \\
\text { Hulu }\end{array}$ \\
\hline Malangbong & Cibatu, Cibatu & $\begin{array}{l}\text { Cimanuk } \\
\text { Hulu }\end{array}$ \\
\hline Cibatu & $\begin{array}{l}\text { Wanakerta, } \\
\text { Cibatu }\end{array}$ & $\begin{array}{l}\text { Cimanuk } \\
\text { Hulu }\end{array}$ \\
\hline
\end{tabular}

3. Data Peta Rencana Tata Ruang Wilayah (RTRW) Garut 2014, diperoleh dari instansi Bappeda Kabupaten Garut

4. Data Peta Potensi Banjir CimanukCisanggarung, diperoleh dari instansi BBWS Cimanuk-Cisanggarung 2016

5. Data Peta RBI (Rupa Bumi Digital Indonesia) Lembar Darmaraja, Lembar Leles, Lembar Malangbong, Lembar Garut, Lembar Samarang dan Lembar Cikajang

6. Peta sungai dan anak-anak Sungai Cimanuk dalam format .shp

7. Data studi terdahulu

8. Data sekunder tambahan lainnya

Selain data sekunder, digunakan data pendukung yang merupakan data tambahan (tidak terhubung langsung dengan teknis perencanaan), sebagai bahan pertimbangan secara menyeluruh terhadap perencanaan, misalnya data hasil pengamatan dan wawancara secara langsung dengan pihak-pihak yang terkait sehingga dapat diketahui kondisi nyatanya, kependudukan, data administrasi pemerintahan dan data tata guna lahan.

\section{Analisis dan Pembahasan}

Analisis penelitian ini secara garis besar dibagi menjadi 5 (lima) tahapan, yaitu pengolahan data hidrologi, simulasi model hidrologi dengan HEC-HMS, simulasi model hidrolika dengan HEC-RAS, analisis genangan banjir, simulasi untuk status peringatan dini banjir dan operasional sistem peringatan dini banjir.

1. Penentuan SubDAS Cimanuk Hulu

Analisis ini dimulai dengan penentuan SubDAS di DAS Cimanuk Hulu. Dalam penelitian ini dibagi menjadi 57 SubDAS.

Pembagian SubDAS Cimanuk Hulu menggunakan program HEC-HMS ditampilkan pada Gambar 2. Total luas SubDAS Cimanuk Hulu adalah sebesar $1247 \mathrm{~km}^{2}$. Titik kontrol untuk pemodelan hidrologi menggunakan program HEC- 
HMS adalah di Bendung Cimanuk di Kecamatan Bayongbong.

Daerah yang akan diberikan peringatan dini adalah daerah yang tergenang akibat limpasan air Sungai Cimanuk di Kawasan Kota Garut, terutama di Kecamatan Tarogong dan Kecamatan Garut Kota.

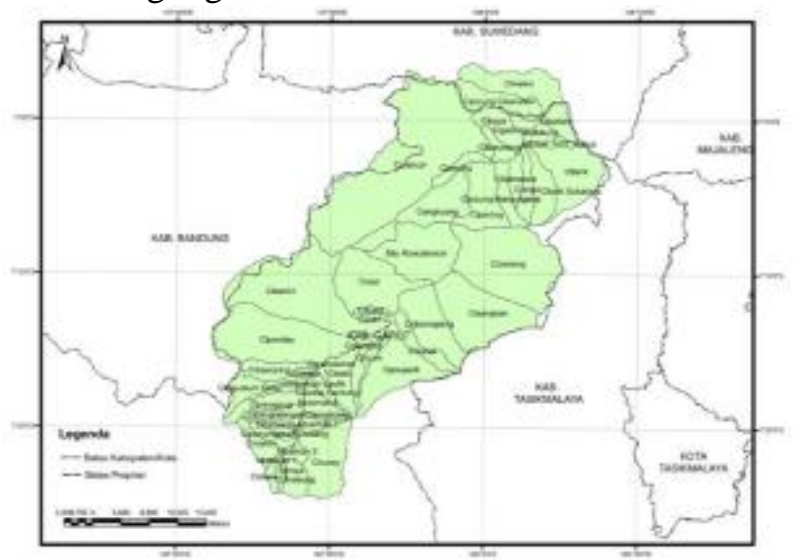

Gambar 2. Pembagian SubDAS Cimanuk Hulu

2. Analisis Hujan DAS

Stasiun hujan yang digunakan untuk analisis hujan DAS adalah stasiun yang memiliki data hujan tahun 1998 sampai dengan tahun 2019 (22 tahun), kemudian dilakukan analisa hujan rata-rata metode poligon Thiessen. Rekapitulasi hujan maksimum harian rata-rata ditampilkan pada Tabel 2 berikut.

Tabel 2. Rekapitulasi Hujan Maksimum

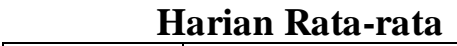

\begin{tabular}{|c|c|}
\hline Tahun & $\begin{array}{c}\text { Hujan Max Harian } \\
\text { Rata-rata DAS (mm) }\end{array}$ \\
\hline 1998 & 43 \\
\hline 1999 & 33 \\
\hline 2000 & 37 \\
\hline 2001 & 40 \\
\hline 2002 & 44 \\
\hline 2003 & 49 \\
\hline 2004 & 50 \\
\hline 2005 & 59 \\
\hline 2006 & 37 \\
\hline 2007 & 36 \\
\hline 2008 & 47 \\
\hline 2009 & 78 \\
\hline 2010 & 56 \\
\hline 2011 & 51 \\
\hline 2012 & 52 \\
\hline 2013 & 54 \\
\hline 2014 & 66 \\
\hline 2015 & 38 \\
\hline 2016 & 84 \\
\hline 2017 & 28 \\
\hline 2018 & 47 \\
\hline
\end{tabular}

\begin{tabular}{|c|c|}
\hline Tahun & $\begin{array}{c}\text { Hujan Max Harian } \\
\text { Rata-rata DAS (mm) }\end{array}$ \\
\hline 2019 & 60 \\
\hline
\end{tabular}

3. Penentuan Curve Number

Curve Number $(\mathrm{CN})$ dan impervious pada Subdas Cimanuk ditentukan dengan menggunakan peta jenis tanah dan peta tata guna lahan Jawa Barat tahun 2012, yang kemudian di overlay menggunakan program ArcGIS 10.2.

Untuk melakukan overlay peta dengan ArcGIS, jenis tanah dan guna lahan harus dilakukan reklasifikasi. Reklasifikasi terhadap jenis tanah secara hidrologis berdasarkan laju infiltrasi, dimana jenis tanah dan guna lahan harus diklasifikasikan berdasarkan kategori A, B, C dan D. Selain jenis tanah, guna lahan atau tutupan lahan juga perlu dilakukan reklasifikasi berdasarkan USCS (Unified Soil Classification System).

4. Simulasi Model Hidrologi dengan HECHMS

Model HEC-HMS v.4.2.1 dapat memberikan simulasi hidrologi dari puncak aliran harian untuk perhitungan debit banjir rencana dari suatu DAS (Daerah Aliran Sungai). Pada basin model tersusun atas gambaran fisik daerah tangkapan air dan sungai. Elemen-elemen hidrologi berhubungan dengan jaringan yang mensimulasikan proses limpasan permukaan (run off).

Pada basin model ini dibutuhkan peta background yang dapat diimport dari CAD (Computer Aided Design) maupun GIS (Geografic Information System). Elemen elemen yang digunakan untuk mensimulasikan limpasan adalah subbasin, reach, dan junction. Model hidrologi DAS Cimanuk Hulu dengan HEC-HMS ditampilkan pada Gambar 3

5. Verifikasi Hujan Kejadian Banjir

Simulasi yang dilakukan dengan menggunakan software HEC-HMS 4.2.1 pada DAS Cimanuk Hulu memberikan hasil yang hampir sesuai dengan kondisi atau parameter DAS Cimanuk Hulu yang sebenarnya. Titik kontrol yang digunakan untuk verifikasi hujan kejadian banjir adalah Bendung Cimanuk, AWLR Bojongloa dan Bendung Copong. 


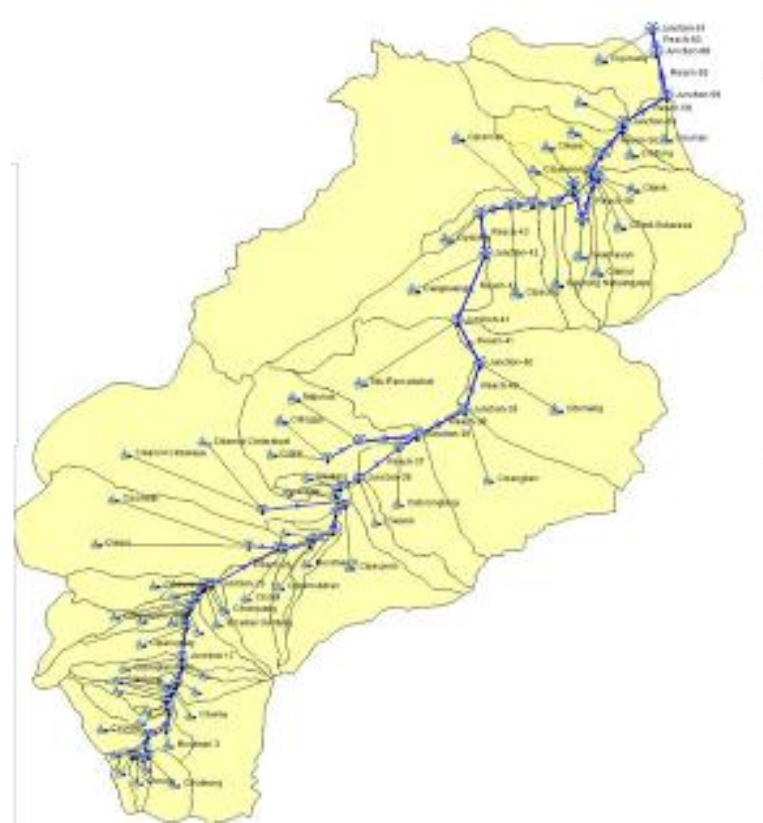

Gambar 3. Model Hidrologi DAS Cimanuk Hulu dengan HEC-HMS 4.2.1

Saat terjadi banjir di DAS Cimanuk Hulu yang mencapai puncak pada tanggal 21 September 2016, diketahui dari pencatatan data debit dan tinggi muka air pada titik kontrol yang ditampilkan pada Tabel 3 berikut.

Tabel 3. Besaran Debit Puncak Tercatat pada Titik Kontrol

\begin{tabular}{|l|c|c|}
\hline Titik Kontrol & $\begin{array}{c}\text { Q saat } \\
\text { banjir 2016 } \\
\left(\mathbf{m}^{\mathbf{3}} / \mathbf{d t}\right)\end{array}$ & $\begin{array}{c}\text { TMA saat } \\
\text { banjir } \\
\mathbf{2 0 1 6}(\mathbf{m})\end{array}$ \\
\hline Bendung Cimanuk & 628 & 3.95 \\
\hline AWLR Bojongloa & 752.3 & 5.80 \\
\hline Bendung Copong & 1006 & 6.62 \\
\hline
\end{tabular}

Pada Bendung Cimanuk dengan tinggi mercu $+1004 \mathrm{~m}$, tinggi muka air tercatat diatas mercu saat kejadian banjir adalah 3.95 meter. Pada Stasiun Duga Air (AWLR) Bojongloa, tinggi muka air tercatat saat kejadian banjir adalah 5,80 meter dihitung dari pelampung terendah (1.5 meter) dari dasar sungai. Sedangkan pada Bendung Copong adalah bendung gerak, maka tinggi muka air saat kejadian banjir adalah 6.62 meter dari as bendung gerak.

Berdasarkan hasil simulasi awal yang telah dilakukan pada Tabel 4, maka dilakukan analisis perbandingan model hidrologi agar besaran debit hasil simulasi pada titik kontrol mendekati nilai yang tercatatat. Pada saat besaran nilai hasil simulasi sama dengan atau mendekati nilai debit puncak banjir tercatat, maka parameter
DAS dapat dinyatakan mewakili kondisi DAS yang sebenarnya.

Tabel 4. Hasil Simulasi Perbandingan Hujan Kejadian dan HEC-HMS

\begin{tabular}{|l|c|c|}
\hline \multicolumn{1}{|c|}{$\begin{array}{c}\text { Titik } \\
\text { Kontrol }\end{array}$} & $\begin{array}{c}\text { Q saat } \\
\text { banjir 2016 } \\
\left(\mathbf{m}^{\mathbf{3}} / \mathbf{d t}\right)\end{array}$ & $\begin{array}{c}\text { Q perhitungan } \\
\text { HEC-HMS } \\
(\mathbf{Q 1 0 0})\left(\mathbf{m}^{\mathbf{3}} / \mathbf{d t}\right)\end{array}$ \\
\hline $\begin{array}{l}\text { Bendung } \\
\text { Cimanuk }\end{array}$ & 628 & $678.5(\mathrm{~J} .22)$ \\
\hline $\begin{array}{l}\text { AWLR } \\
\text { Bojongloa }\end{array}$ & 752.3 & $740.1(\mathrm{~J} .28)$ \\
\hline $\begin{array}{l}\text { Bendung } \\
\text { Copong }\end{array}$ & 1060 & $995.3(\mathrm{~J} .37)$ \\
\hline
\end{tabular}

6. Simulasi Model Hidrolika dengan HECRAS

Untuk memodelkan hidrolika dengan HEC-RAS, yang dilakukan pertama kali adalah pemodelan geometri sungai yaitu peniruan alur sungai dan input data cross section penampang sungai. Alur Sungai Cimanuk yang akan di input adalah Sungai Cimanuk bagian hulu, yaitu dari STA 0 hingga STA 97. Cross STA 97 adalah Bendung Cimanuk dan STA 0 adalah Bendung Copong yang terletak di kawasan Perkotaan Garut. Jarak antara cross section di setiap STA berbeda-beda. Cross section dengan jarak yang lebih rapat terdapat pada alur sungai di kawasan Perkotaan Garut yang rawan banjir. Aliran sungai mengalir dari STA 97 menuju STA 0. Geometri sungai Cimanuk di kawasan Kota Garut ditampilkan pada Gambar 4 berikut.

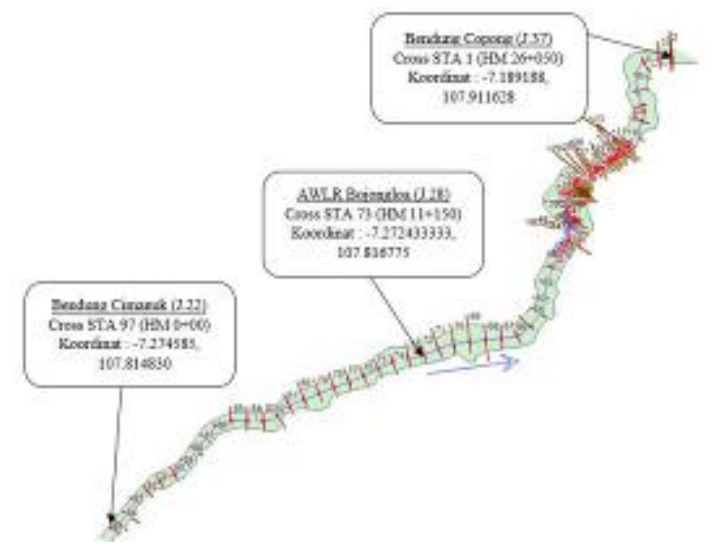

\section{Gambar 4. Peniruan Geometri Sungai} Cimanuk pada HEC-RAS

Setelah peniruan geometri sungai selesai, dilakukan input data debit rencana dari output program HEC-HMS. Data debit yang digunakan untuk running, terbagi menjadi 3 (tiga) masukan, yaitu pertama adalah debit dari STA 0 s/d STA 50, yang kedua adalah STA 51 s/d STA 76 dan yang ketiga adalah STA 77 
s/d STA 97. Debit rencana yang dipakai untuk running HEC-RAS ditampilkan pada Gambar 5.

Berdasarkan hasil simulasi menunjukkan bahwa daerah yang terkena banjir adalah pada 9 desa atau 6 kecamatan yaitu Kecamatan Bayongbong, Cisurupan, Cilawu, Tarogong, Garut Kota dan Banyuresmi. Hasil debit kala ulang penyebab banjir ditampilkan pada Tabel $\mathbf{5}$ berikut.

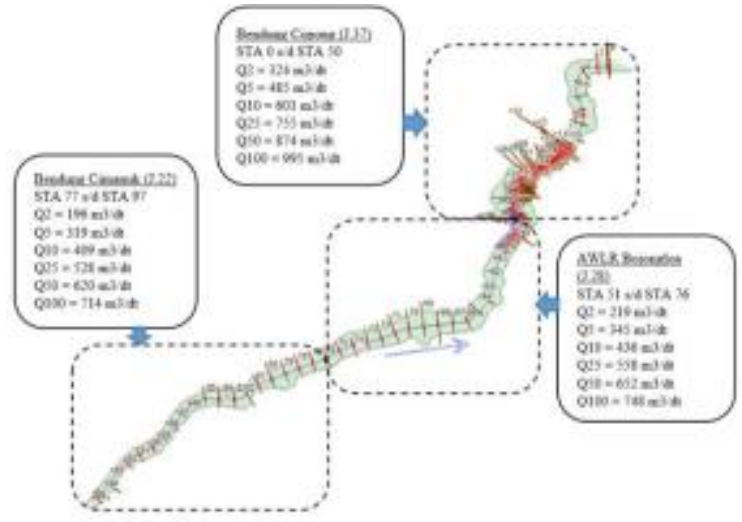

Gambar 5. Debit Rencana yang Dipakai untuk Running HEC-RAS

Tabel 5. Hasil Simulasi Banjir Kala Ulang

\begin{tabular}{|c|l|l|}
\hline $\begin{array}{c}\text { River } \\
\text { Station } \\
\text { (STA) }\end{array}$ & \multicolumn{1}{|c|}{$\begin{array}{c}\text { Lokasi (Desa, } \\
\text { Kecamatan) }\end{array}$} & $\begin{array}{l}\text { Debit Kala } \\
\text { Ulang } \\
\text { Penyebab } \\
\text { Banjir }\end{array}$ \\
\hline 92 & Bayongbong Bayongbong & $\begin{array}{l}\text { Q25, Q50, } \\
\text { Q100 }\end{array}$ \\
\hline 91 & Cilea Bayongbong & $\begin{array}{l}\text { Q5, Q10, } \\
\text { Q25, Q50, } \\
\text { Q100 }\end{array}$ \\
\hline 79 & Sukarame Bayongbong & $\begin{array}{l}\text { Q25, Q50, } \\
\text { Q100 }\end{array}$ \\
\hline 43 & Sukakarya Cisurupan & $\begin{array}{l}\text { Q5, Q10, } \\
\text { Q25, Q50, } \\
\text { Q100 }\end{array}$ \\
\hline 33 & Sukajaya Cilawu & $\begin{array}{l}\text { Q5, Q10, } \\
\text { Q25, Q50, } \\
\text { Q100 }\end{array}$ \\
\hline 28 & Jayawaras Tarogong & Q50, Q100 \\
\hline 23 & Pakuwon Garut Kota & $\begin{array}{l}\text { Q10, Q25, } \\
\text { Q50, Q100 }\end{array}$ \\
\hline 18 & Haurpanggung Tarogong & $\begin{array}{l}\text { Q10, Q25, } \\
\text { Q50, Q100 }\end{array}$ \\
\hline 1 & Mekarsari Banyuresmi & $\begin{array}{l}\text { Q25, Q50, } \\
\text { Q100 }\end{array}$ \\
\hline
\end{tabular}

7. Analisis Genangan Banjir

Analisis genangan banjir menggunakan program HEC-RAS 2D yaitu program HECRAS versi 5 . Data yang dibutuhkan adalah peta DEM yang diperoleh dari website Earth Explorer dan BBWS Cimanuk-
Cisanggarung. Genangan banjir di Sungai Cimanuk dengan kala ulang Q50 dan Q100tahun menggunakan program HEC-RAS ditampilkan pada Gambar 6 sampai dengan Gambar 9 berikut.

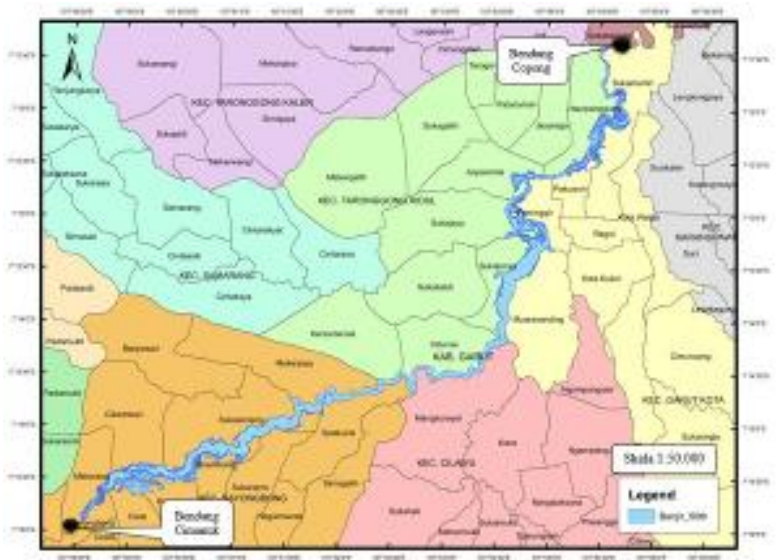

Gambar 6. Genangan Banjir Sungai Cimanuk Kala Ulang Q50

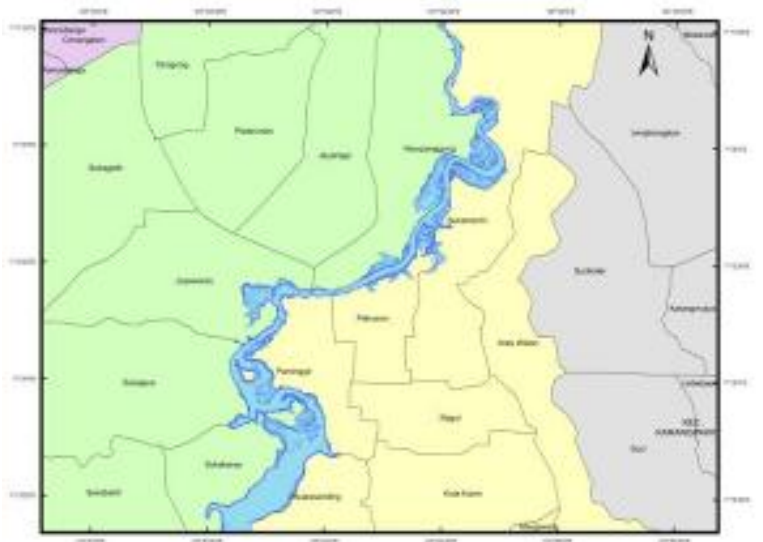

Gambar 7. Genangan Banjir Sungai Cimanuk per Desa Kala Ulang Q50

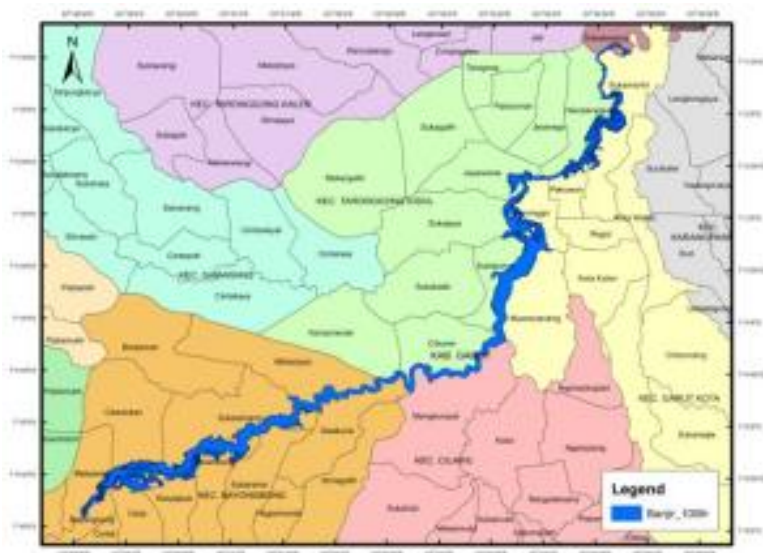

Gambar 8. Genangan Banjir Sungai Cimanuk Kala Ulang Q100 


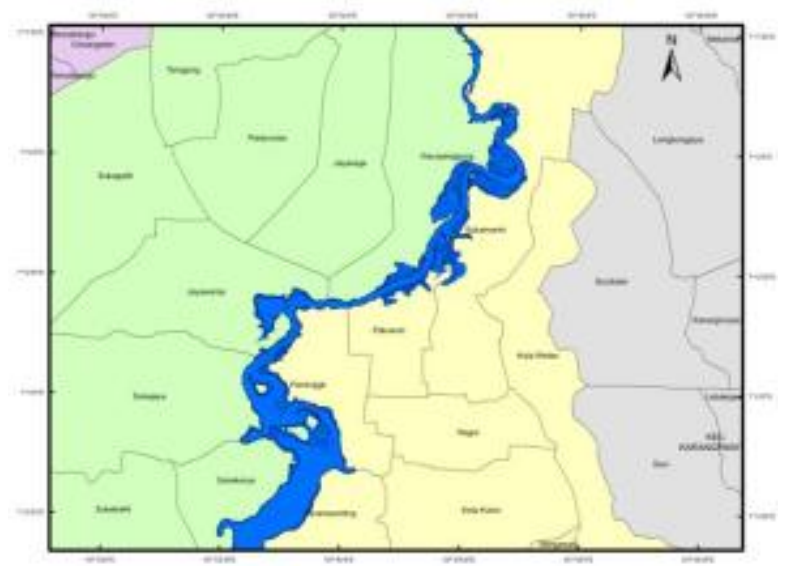

\section{Gambar 9. Genangan Banjir Sungai \\ Cimanuk per Desa Kala Ulang Q100}

Output genangan banjir kala ulang Q50 dan Q100 tahun berupa luas area genangan, yang bisa didapatkan dari attribute table menggunakan data shapefile (.shp) dengan menggunakan program ArcGIS v.10.2. Diperoleh total luas area genangan banjir Q50 tahun sebesar $2.976 \mathrm{~km}^{2}$ dan Q100 sebesar $3.222 \mathrm{~km}^{2}$. Genangan banjir di kawasan Kota Garut per desa dan kecamatan ditampilkan pada Tabel 6 berikut ini.

Tabel 6. Luas Genangan Banjir Per Desa dan Kecamatan

\begin{tabular}{|c|c|c|c|}
\hline \multirow{2}{*}{ Kecamatan } & \multirow{2}{*}{$\begin{array}{c}\text { Desa / } \\
\text { Kelurahan }\end{array}$} & \multicolumn{2}{|c|}{ Luas Genangan Banjir $\left(\mathbf{m}^{2}\right)$} \\
\hline & & Q50 tahun & Q100 tahun \\
\hline \multirow[t]{2}{*}{ Banyuresmi } & & 20293.016 & 23849.717 \\
\hline & Sukasenang & 20293.016 & 23849.717 \\
\hline \multirow[t]{11}{*}{ Bayongbong } & & 1399784.028 & 1479376.409 \\
\hline & Bayongbong & 48424.834 & 50717.426 \\
\hline & Ciela & 94169.443 & 102531.294 \\
\hline & Cikedokan & 67672.664 & 69336.361 \\
\hline & Karyajaya & 263124.935 & 274449.511 \\
\hline & Mekarjaya & 110257.799 & 114144.066 \\
\hline & Mekarsari & 54221.619 & 64409.066 \\
\hline & Panembong & 240797.808 & 261656.550 \\
\hline & Salakurai & 120113.813 & 127283.618 \\
\hline & Sukarame & 8163.262 & 8687.824 \\
\hline & Sukasenang & 392837.851 & 406160.693 \\
\hline \multirow[t]{2}{*}{ Cilawu } & & 123783.084 & 143181.883 \\
\hline & Mangkurayat & 123783.084 & 143181.883 \\
\hline \multirow[t]{5}{*}{ Garut Kota } & & 620826.292 & 687343.725 \\
\hline & Muarasanding & 216306.526 & 227859.577 \\
\hline & Pakuwon & 53692.357 & 73147.165 \\
\hline & Paminggir & 182754.032 & 195219.079 \\
\hline & Sukamantri & 168073.377 & 191117.904 \\
\hline \multirow[t]{7}{*}{$\begin{array}{l}\text { Taronggong } \\
\text { Kidul }\end{array}$} & & 812070.341 & 888652.170 \\
\hline & Cibunar & 113509.071 & 128869.822 \\
\hline & Haurpanggung & 228187.822 & 239890.539 \\
\hline & Jayawaras & 78075.657 & 88496.901 \\
\hline & Kersamenak & 19323.891 & 20413.732 \\
\hline & Sukajaya & 25723.332 & 29303.921 \\
\hline & Sukakarya & 347250.568 & 381677.255 \\
\hline \multicolumn{2}{|c|}{ Grand Total } & 2976756.761 & 3222403.904 \\
\hline
\end{tabular}

8. Simulasi Peringatan Dini Banjir Kota Garut

Indikator yang digunakan dalam simulasi peringatan dini banjir adalah indikator tinggi muka air. Indikator tinggi muka air digunakan sebagai indikator karena memiliki akurasi yang lebih tinggi dibandingkan dengan indikator curah hujan. Juga mudah dipahami oleh masyarakat.

Tinggi muka air diamati pada Bendung Cimanuk akan dijadikan acuan pada peringatan dini banjir Sungai Cimanuk, dimana hasil simulasi banjir pada setiap kala ulang pada lokasi tinjauan, maka peringatan dapat direncanakan berdasarkan waktu akan mulai meluapnya Sungai Cimanuk akibat banjir kala ulang.

Terdapat 4 (empat) status level peringatan dini dan penamaan istilah kriteria status level tersebut pada penelitian ini adalah sebagai berikut :

a. Siaga Banjir I (status level Normal), apabila kondisi muka air dengan ketinggian 2.5 meter di bawah permukaan tanggul (tinggi jagaan 2.5 meter).

b. Siaga Banjir II (status level Waspada), apabila kondisi muka air dengan ketinggian 1.5 meter dari permukaan tanggul (tinggi jagaan 1.5 meter).

c. Siaga Banjir III (status level Siaga), apabila kondisi muka air dengan ketinggian 0.5 meter dari permukaan tanggul (tinggi jagaan 0.5 meter).

d. Siaga Banjir IV (status level Awas), apabila kondisi muka air dengan ketinggian yang sama dengan tinggi tanggul hingga melimpas

Sket 4 (empat) status level peringatan dini tersebut ditampilkan pada Gambar 10 diambil pada STA 92 di Desa Bayongbong (HM. 32+00).

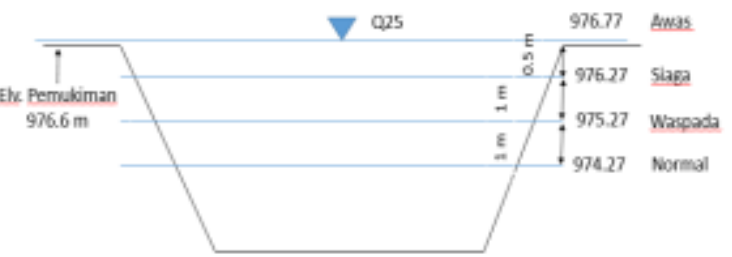

Gambar 10. Sket Status Peringatan Dini di Desa Bayongbong (HM. 32+00) 
Pada tabel simulasi banjir, dilakukan pengecekan debit kala ulang berapa yang menyebabkan banjir di setiap cross section, kemudian bandingkan hasil output HECRAS yaitu W.S. Elv (Water Surface Elevation) dengan tanggul kanan dan kiri tiap penampang sungai. Apabila W.S Elv > LOB \& ROB, maka cross sungai dinyatakan banjir.

Ada 25 desa yang berada di daerah sempadan Sungai Cimanuk Hulu, dari titik kontrol Bendung Cimanuk sampai dengan Bendung Copong. Dari 25 desa tersebut terdapat 9 desa di kawasan Kota Garut yang terdampak banjir di Sungai Cimanuk Hulu. Hasil simulasi banjir ditampilkan pada Tabel 7 dan Skema Peringatan Dini ditampilkan pada Gambar 11.

9. Operasional Sistem Peringatan Dini Banjir Sungai Cimanuk di Kota Garut

Tujuan peringatan dini yang berbasis masyarakat adalah untuk memberdayakan individu dan masyarakat yang terancam bahaya untuk bertindak dalam waktu yang cukup dan dengan cara yang tepat untuk mengurangi kemungkinan terjadinya korban luka, hilangnya jiwa serta rusaknya harta benda dan lingkungan (BNPB, 2012).

Sebagai lokasi acuan yang digunakan sebagai indikator tinggi muka air peringatan dini banjir berdasarkan debit banjir kala ulang, Bendung Cimanuk perlu diberikan kondisi batas peringatan.

Penentuan kondisi batas mengacu pada empat status peringatan yaitu Normal, Waspada, Siaga, dan Awas. Pada sistem peringatan dini, status peringatan tersebutdapat diberikan tanda dengan warna yaitu warna biru untuk status Normal, warna hijau untuk status waspada, warna kuning untuk status siaga dan warna merah untuk status awas.

a) Kondisi level waspada merupakan suatu keadaan dimana terjadi peningkatan ancaman dan resiko yang dibuktikan dengan hasil analisi data-data dan informasi ilmiah yang menunjukan aktifitas ancaman diatas rata-rata dari kondisi normal. Pada Kondisi ini, jika hujan terjadi pengamat pos curah hujan memantau ketinggian hujan dan kapan hujan mulai dan berhenti, hingga diketahui durasinya.
Tabel 7. Hasil Simulasi Banjir Kota Garut pada Cross Section Sungai Cimanuk

\begin{tabular}{|c|c|c|c|c|c|c|c|}
\hline No. & $\begin{array}{l}\text { LOKASI (DESA, } \\
\text { KECAMATAN) }\end{array}$ & HM & $\begin{array}{l}\text { LOKASI } \\
\text { PEMUKI } \\
\text { MAN }\end{array}$ & $\begin{array}{c}\text { ELEVASI } \\
\text { PEMUKI } \\
\text { MAN ( } \pm \\
\mathrm{m} \text { ) }\end{array}$ & $\begin{array}{c}\text { STATUS } \\
\text { BENCANA }\end{array}$ & $\begin{array}{l}\text { TMA DI } \\
\text { CS }\end{array}$ & $\begin{array}{l}\text { TMA DI BD } \\
\text { CIMANUK }\end{array}$ \\
\hline \multirow{4}{*}{1} & \multirow{4}{*}{$\begin{array}{l}\text { Bayongbong, } \\
\text { Bayongbong }\end{array}$} & \multirow{4}{*}{$32+00$} & \multirow{4}{*}{$\begin{array}{l}\text { Kanan } \\
\text { Sungai }\end{array}$} & \multirow{4}{*}{976.6} & Normal & 974.27 & 1006.95 \\
\hline & & & & & \begin{tabular}{|l} 
Waspada \\
\end{tabular} & 975.27 & 1007.95 \\
\hline & & & & & Siaga & 976.27 & 1008.95 \\
\hline & & & & & Awas & 976.77 & 1009.45 \\
\hline \multirow{4}{*}{2} & \multirow{4}{*}{$\begin{array}{c}\text { Cilea, } \\
\text { Bayongbong }\end{array}$} & \multirow{4}{*}{$37+00$} & \multirow{4}{*}{$\begin{array}{l}\text { Kanan } \\
\text { Sungai }\end{array}$} & \multirow{4}{*}{972.3} & Normal & 970.27 & 1005.82 \\
\hline & & & & & \begin{tabular}{|l} 
Waspada \\
\end{tabular} & 971.27 & 1006.82 \\
\hline & & & & & Siaga & 972.27 & 1007.82 \\
\hline & & & & & Awas & $\begin{array}{l}972.47 \\
\end{array}$ & 1008.32 \\
\hline \multirow{4}{*}{3} & \multirow{4}{*}{$\begin{array}{l}\text { Sukarame, } \\
\text { Bayongbong }\end{array}$} & \multirow{4}{*}{$97+00$} & \multirow{4}{*}{$\begin{array}{l}\text { Kanan } \\
\text { Sungai }\end{array}$} & \multirow{4}{*}{901.0} & Normal & 898.80 & 1006.95 \\
\hline & & & & & Waspada & 899.80 & 1007.95 \\
\hline & & & & & Siaga & 900.80 & 1008.95 \\
\hline & & & & & Awas & 901.30 & 1009.45 \\
\hline \multirow{4}{*}{4} & \multirow{4}{*}{$\begin{array}{l}\text { Sukakarya, } \\
\text { Cisurupan }\end{array}$} & \multirow{4}{*}{$212+00$} & \multirow{4}{*}{$\begin{array}{c}\text { Kiri } \\
\text { Sungai }\end{array}$} & \multirow{4}{*}{735.0} & Normal & 730.26 & 1005.82 \\
\hline & & & & & Waspada & 731.26 & 1006.82 \\
\hline & & & & & Siaga & 732.26 & 1007.82 \\
\hline & & & & & Awas & 732.76 & 1008.32 \\
\hline \multirow{4}{*}{5} & \multirow{4}{*}{$\begin{array}{c}\text { Sukajaya, } \\
\text { Cilawu }\end{array}$} & \multirow{4}{*}{$217+00$} & \multirow{4}{*}{$\begin{array}{c}\text { Kiri } \\
\text { Sungai }\end{array}$} & \multirow{4}{*}{730.0} & Normal & 729.40 & 1005.82 \\
\hline & & & & & \begin{tabular}{|l} 
Waspada \\
\end{tabular} & 730.40 & 1006.82 \\
\hline & & & & & Siaga & 731.40 & 1007.82 \\
\hline & & & & & Awas & 731.90 & 1008.32 \\
\hline \multirow{4}{*}{6} & \multirow{4}{*}{$\begin{array}{c}\text { Jayawaras, } \\
\text { Tarogong }\end{array}$} & & & & Normal & 729.14 & 1007.40 \\
\hline & & $232+0$ & Kiri & 7280 & Waspada & 730.14 & 1008.40 \\
\hline & & $2 \angle Z+U 0$ & Sungai & 120.0 & Siaga & 731.14 & 1009.40 \\
\hline & & & & & Awas & 731.64 & 1009.90 \\
\hline & & & & & Normal & 725.56 & 1006.33 \\
\hline 7 & Pakuwon, & $227+00$ & Kanan & 7270 & \begin{tabular}{|l} 
Waspada \\
\end{tabular} & 726.56 & 1007.33 \\
\hline & Garut Kota & & Sungai & 127.0 & Siaga & 727.56 & 1008.33 \\
\hline & & & & & Awas & 728.06 & 1008.83 \\
\hline & & & & & Normal & 723.30 & 1006.33 \\
\hline 8 & Haurpanggung, & $232+00$ & Kiri & 7230 & \begin{tabular}{|l} 
Waspada \\
\end{tabular} & 724.30 & 1007.33 \\
\hline & Tarogong & & Sungai & & Siaga & 725.30 & 1008.33 \\
\hline & & & & & Awas & 725.80 & 1008.83 \\
\hline & & & & & Normal & 704.70 & 1006.95 \\
\hline 9 & Mekarsari, & $276+00$ & Kiri & 707.0 & \begin{tabular}{|l} 
Waspada \\
\end{tabular} & 705.70 & 1007.95 \\
\hline & Banyuresmi & & Sungai & & Siaga & 706.70 & 1008.95 \\
\hline & & & & & Awas & 707.20 & 1009.45 \\
\hline
\end{tabular}
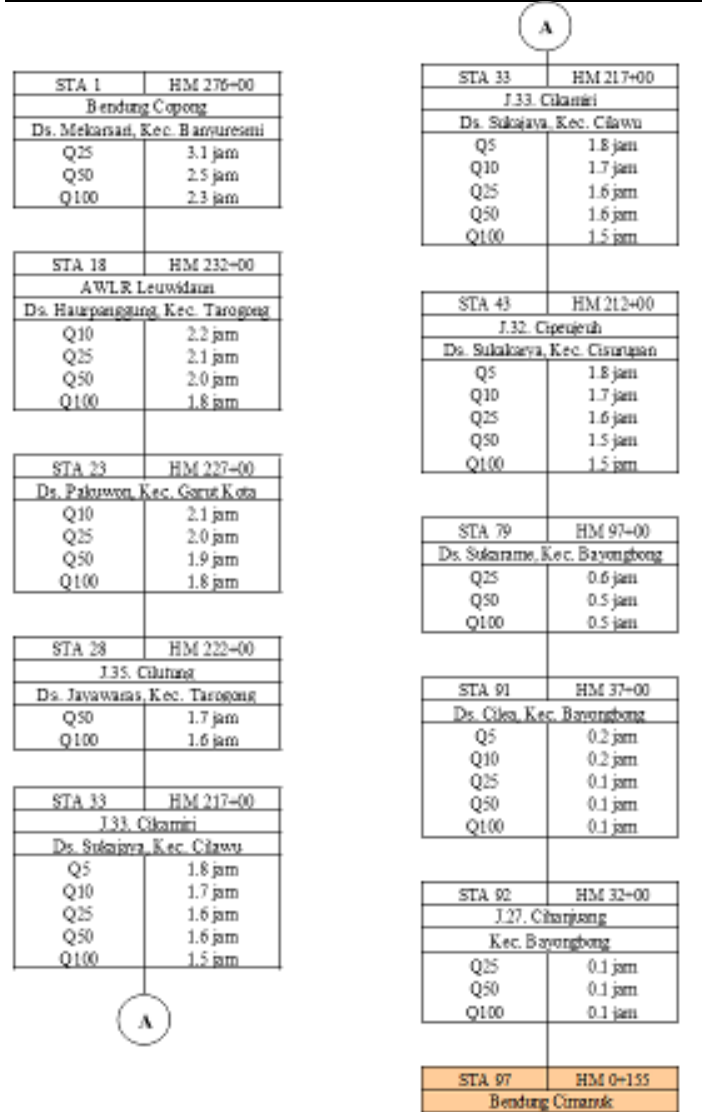

Gambar 11. Skema Peringatan Dini Banjir di Kota Garut 
b) Kondisi level siaga yaitu kondisi dimana terjadi peningkatan ancaman dan resiko yang signifikan tetapi masih dapat dikendalikan sehingga sewaktu jika status kedaruratan dinaikan levelnya, maka seluruh sumber daya dapat segera dikerahkan untuk melakukan penyelamatan dan evakuasi masyarakat serta pengamanan asset. Pada kondisi ini, petugas posko dan petugas di lokasi yang berpotensi terdampak luapan Sungai Cimanuk sudah harus memberikan informasi kepada masyarakat untuk berkemas misalnya mengemas suratsurat dan barang berharga, pakaian dan makanan untuk persiapan mengungsi beberapa hari, jika terdapat anak kecil dan orang lanjut usia segera disiapkan segala kebutuhannya, barang-barang berharga yang tidak dapat dibawa untuk mengungsi agar ditempatkan di tempat yang lebih tinggi yang tidak terjangkau air jika banjir terjadi, dan menyiapkan kendaraan seperti motor dan mobil.

c) Kondisi level awas adalah kondisi dengan tingkat ancaman dan resiko sedemikian tinggi sehingga membahayakan masyarakat dimana pada kondisi ini evakuasi sudah dilakukan. Evakuasi dilakukan oleh petugas di lapangan dengan bantuan berbagai pihak. Masyarakat yang terkena dampak banjir harus evakuasi ke tempat yang lebih aman yaitu ketempat disekitar desa/kelurahan yang elevasi ketinggian lokasi nya lebih tinggi dari tinggi muka air maksimum yang dapat terjadi di desa atau kelurahan tersebut.

\section{PENUTUP}

\section{Simpulan}

Berdasarkan hasil penelitian, maka dapat dirumuskan beberapa kesimpulan sebagai berikut :

1. Hujan yang dapat menyebabkan banjir di Kota Garut adalah hujan dengan kala ulang lebih besar atau sama dengan, yaitu:

a. Kala ulang 5 tahun di Desa Cilea Kecamatan Bayongbong, Desa Sukakarya Kecamatan Cisurupan dan Desa Sukajaya di Kecamatan Cilawu

b. Kala ulang 10 tahun di Desa Pakuwon Kecamatan Garut Kota dan Desa
Haurpanggung
Kecamatan
Tarogong
c. Kala ulang 25 tahun di
Desa Bayongbong Kecamatan
Bayongbong, Desa Sukarame
Kecamatan Bayongbong dan Desa
Mekarsari
Kecamatan
Banyuresmi
d. Kala ulang 50 tahun di
Desa Jayawaras Kecamatan
Tarogong

2. Desa yang berada di luar Kawasan Kota Garut, yang memiliki waktu tempuh yang paling cepat untuk evakuasi adalah:

a. Desa Bayongbong (STA 92) dan

Desa Cilea (STA 91) di

Kecamatan Bayongbong, yaitu 0.1 jam (6 menit) jika banjir terjadi dengan $\mathrm{Q} \geq \mathrm{Q} 50$ tahun

b. Desa yang berada di dalam Kawasan Kota Garut, yang memiliki waktu evakuasi paling cepat adalah Desa Sukakarya dan Desa Cisurupan di Kecamatan Bayongbong, yaitu 1.5 jam (90 menit) jika banjir terjadi dengan Q $\geq$ Q50 dan Q100 tahun.

3. Luas area genangan banjir di Sungai Cimanuk pada kawasan Kota Garut dengan kala ulang 50 tahun adalah sebesar $2.976 \mathrm{~km} 2$, dan kala ulang 100 tahun adalah sebesar $3.222 \mathrm{~km}^{2}$.

4. Sistem peringatan dini banjir yang digunakan pada Kota Garut di DAS Cimanuk Hulu adalah dengan indikator tinggi muka air sebagai acuan peringatan, dengan status level peringatan dini yaitu :

a. Siaga Banjir I (status level Normal), apabila kondisi muka air dengan

ketinggian 2.5 meter di bawah permukaan tanggul (tinggi jagaan 2.5 meter).

b. Siaga Banjir II (status level Waspada), apabila kondisi muka air dengan ketinggian 1.5 meter dari permukaan tanggul (tinggi jagaan 1.5 meter).

c. Siaga Banjir III (status level Siaga), apabila kondisi muka air dengan ketinggian 0.5 meter dari permukaan tanggul (tinggi jagaan 0.5 meter).

d. Siaga Banjir IV (status level Awas), apabila kondisi muka air dengan ketinggian yang sama dengan tinggi 
tanggul hingga melimpas

5. Level peringatan banjir ditentukan berdasarkan saat air Sungai Cimanuk mulai meluap pemukiman di 6 (enam) kecamatan.

\section{Saran}

Saran yang dapat diberikan mengacu pada penelitian ini adalah sebagai berikut:

1. Desa Bayongbong (STA 92) dan Desa Cilea (STA 91) di Kecamatan Bayongbong mempunyai waktu tempuh hanya sebesar 0.1 jam (6 menit) jika banjir terjadi dengan $\mathrm{Q} \geq \mathrm{Q} 50$ tahun, karena Bendung Cimanuk sebagai titik kontrol berada di lokasi yang dekat dengan Kecamatan Bayongbong. Maka diperlukan beberapa tambahan Pos Pengamat TMA di bagian hulu Bendung Cimanuk.

2. Untuk menambah waktu tempuh supaya memperoleh hasil peringatan dini secara komprehensif, perlu diteliti lebih lanjut dan dipasang beberapa tambahan Pos Pengamat TMA di anak-anak Sungai Cimanuk.

3. Penelitian ini tidak mengkaji proses evakuasi dan mitigasi bencana selain peringatan dini, sehingga untuk kepentingan pengelolaan bencana alam diperlukan penelitian lebih lanjut terkait hal tersebut.

\section{DAFTAR PUSTAKA}

Alwi, Iping Mariandana. 2016. Analisis Perencanaan Peringatan Dini Banjir di Sungai Cimanuk. Yogyakarta: Universitas Gadjah Mada.

Aziz, M. A. F., 2014. Analisis Waktu Perjalanan Banjir Bengawan Solo. Yogyakarta: Universitas Gadjah Mada.

BNPB, 2012. Pedoman Sistem Peringatan Dini Berbasis Masyarakat. Jakarta: BNPB.

Br., Sri Harto. 1993. Analisis Hidrologi. Gramedia Pustaka Utama, Jakarta.

Br., Sri Harto. 2000. Hidrologi Teori Masalah Penyelesaian. Yogyakarta: Nafiri.

Chow, V., Maidment, D. \& Mays, L., 1988. Applied Hydraulogy. New York: McGraw Hill Inc.

Feldman, A. D., 2000. Hydrologic Modeling System HEC-HMS Technical Reference Manual. USA: HEC USACE.

Hadisusanto, N., 2010. Aplikasi Hidrologi. Malang: Jogja Mediautama.
Indarto, 2010. Hidrologi, Dasar Teori dan Contoh Aplikasi Model Hidrologi. Jakarta: Bumi Aksara.

Istiarto, 2012. Simulasi Aliran 1Dimensi dengan Bantuan Paket Program Hidrodinamika HEC-RAS. [Online] Available at:

http://istiarto.staff.ugm.ac.id/ [Accessed 2020].

Istiarto. 2018. Simulasi Aliran 1 Dimensi dengan Bantuan HEC-RAS. Yogyakarta: UGM

Kementerian Pekerjaan Umum (PSN 2012). 2012. Pedoman Penyusunan Sistem Peringatan Dini dan Evakuasi untuk Banjir Bandang

Kementerian Hukum dan Hak Asasi Manusia, 2007. Undang-Undang Republik Indonesia Nomor 24 Tahun 2007 tentang Penanggulangan Bencana. Jakarta: Sekretariat Negara Republik Indonesia.

Departemen Pemukiman dan Prasarana Wilayah. 2004. Peramalan Banjir dan Peringatan Dini

Kodoatie, R.J. dan Sugiyanto, 2002. Banjir, Beberapa Penyebab dan Metode Pengendaliannya dalam Perspektif Lingkungan. Yogyakarta: Pustaka Pelajar.

Limantara, L. M., 2010. Hidrologi Praktis. Bandung: Penerbit Lubuk Agung.

Muslimin, Immawan. 2010. Peringatan Dini Banjir Sungai Babak Untuk Pengurangan Resiko Bencana di Kabupaten

Lombok Barat Provinsi Nusa Tenggara Barat. Yogyakarta: Universitas Gadjah Mada

Mutaqin, R. Z. 2014. Kajian Pengendalian Banjir DAS Ciujung. Yogyakarta: Universitas Gadjah Mada

Peraturan Pemerintah No. 21. 2008. Penyelenggaraan Penanggulangan Bencana

Setyawan, N., 2010. Kajian Sistem Peringatan Dini Banjir di Daerah Aliran Sungai Garang. Yogyakarta: Universitas Gadjah Mada.

Soemarto, C.D. 1987. Hidrologi Teknik. Surabaya: Usaha Nasional

Soewarno, 1995. Hidrologi. Bandung: Penerbit Nova.

Sujono, J., 2009. Petunjuk Singkat 
Aplikasi HEC-HMS Versi 3.3. Yogyakarta: Jurusan Teknik Sipil dan Lingkungan

Fakultas Teknik Universitas Gadjah Mada. Suripin. 2003. Sistem Drainase Perkotaan Berkelanjutan. Yogyakarta: ANDI

Triatmodjo, B., 2008. Hidrologi Terapan. Yogyakarta: Beta Offset. 